\title{
PARTISIPASI POLITIK PEMILIH PEMULA DALAM BINGKAI JEJARING SOSIAL DI MEDIA SOSIAL
}

\author{
Loina Lalolo Krina Perangin-angin ${ }^{1}$ dan Munawaroh Zainal ${ }^{2}$ \\ Universitas Swiss German \\ Jl. Jalur Sutera Barat No.15, The Prominence Tower, Alam Sutera, Tangerang 15143 \\ Telp. (021) 29779597 \\ Email : loina.peranginangin@sgu.ac.id ${ }^{1}$, munawaroh.zainal@sgu.ac.id ${ }^{2}$
}

\begin{abstract}
The purpose of this research to identify the social networking of early voters in the social media and its influence toward political participation. Using qualitative approach, the data is primarily collected through focus group discussion and in-depth interview with 63 college students chosen purposively in 3 big cities; Bandung, Jakarta, and Surabaya. Research results show that social media is massively used by the early voters for interacting and communicating because it needs no physical preparation and revelation of their original personality. The network is easily accessed, both on campus and at home, which sustains higher intensity in using social media. While networking socially, the early voters only interact and communicate with old acquaints, thus the networking does not aim for developing a new network. Their participation in politics is considered low, have less understanding about politics, and have not participated yet, both online and offline. Social media has become their primary source of political news and information for discussing with family and peers face-to-face. Discussion result becomes a consideration for their political decision making. The contribution of this research is to give perspectives on political participation of novice voters in social media in order to motivate social media users to become politically literate.
\end{abstract}

Keywords: political participation, early voters, social networking, social media

\begin{abstract}
Abstrak
Tujuan penelitianiniadalah untuk mengidentifikasijaringan sosial para pemilih pemula di dalam media sosial serta pengaruhnya pada partisipasi politik. Metode penelitian ini menggunakan pendekatan kualitatif, data penelitian dikumpulkan melalui diskusi terarah dan wawancara mendalam kepada 63 orang mahasiswa yang terpilih secara purposif di 3 kota besar; Bandung, Surabaya, dan Jakarta. Hasil penelitian menunjukkan media sosial telah digunakan secara massif oleh para pemilih pemula karena melalui media sosial mereka dapat berinteraksi dan berkomunikasi tanpa memerlukan persiapan fisik maupun keharusan untuk memperlihatkan atribut kepribadian secara terbuka. Jaringan Internet dapat diakses dengan mudah, baik di kampus maupun di rumah, sehingga intensitas menggunakan media sosial menjadi sangat tinggi. Didalam berjejaring, interaksi dan komunikasi hanya dilakukan dengan orang-orang yang telah dikenal sebelumnya sehingga berjejaring tidak bertujuan untuk membuat jaringan baru, tetapi memperkuat jejaring lama dalam dunia nyata. Kontribusi penelitian ini adalah memberikan wawasan mengenai partisipasi politik pemilih pemula di media sosial dengan harapan bisa memotivasi agar pengguna media social juga berusaha untuk bisa melek politik.
\end{abstract}

Kata kunci : partisipasi politik, pemilih pemula, jaringan sosial, media sosial

\section{Pendahuluan}

Banyak negara saat ini mengalami partisipasi pemilih pemula dalam politik sangat rendah dibandingkan dengan generasi yang lebih tua. Pada kasus yang ada di Indonesia, misalnya, Sodikin, et.al. (2013) mencatat jumlah non-voter (biasa disebut golongan putih atau golput) yang terutama didominasi oleh kaum muda, terus meningkat dari pemilu ke pemilu berikutnya; 10,21\% pada Pemilu 1999, meningkat menjadi 23,34\% pada Pemilu 2004, dan 39,10 \% pada Pemilu 2009.

Disisi lain, sejak Era Reformasi dimulai, rakyat Indonesia mengalami keterbukaan 
informasi dengan semakin meningkatnya jumlah media massa, baik cetak maupun elektronik. Indonesia merayakan demokrasi setelah 32 tahun berada dibawah bayangbayang rezim Orde Baru. Dengan kebebasan berbicara dan berpendapat, rakyat Indonesia seharusnya lebih terdidik secara politik dan memiliki lebih banyak pilihan.

Era Reformasi juga ditandai dengan lahirnya situs berita online seperti detik.com, beritanet.com, kompas.com, tempo.co.id, antara.com dan lainnya yang memungkinkan berita dan informasi politik sampai ke khalayak luas dengan cepat tanpa memerlukan biaya besar. Setiap orang memiliki peluang untuk terlibat dalam proses produksi maupun distribusi berita dan informasi. Ditambah dengan lahirnya situs-situs jaringan sosial, khalayak semakin mudah untuk saling berbagi berita dan informasi politik.

Lingkungan politik yang semakin terbuka ternyata tidak mampu meningkatkan partisipasi politik generasi muda. Bagi kaum muda, politik seringkali dianggap terlalu formal, bahkan banyak diantara mereka yang menolak bicara tentang politik. Pada Pemilu 2014, 63\% dari pemilih tinggal di Pulau Jawa, dimana 19,7 juta diantaranya adalah pemilih pemula dengan rentang usia 17-21 tahun dan 57\% diantaranya adalah pemilih muda yang akrab dengan penggunaan media (media literacy). Mereka ini adalah penduduk digital yang akrab dengan media sosial, memenuhi ruang publik dengan komentar yang cepat, pedas, tegas, kadang kasar, dan mudah berpindah dari satu isu ke isu lain yang lebih atraktif.

Keputusan politik memang tidak diambil di dalam sebuah ruang hampa. Zuckerman
(2005) menjelaskan bahwa lingkungan sekitar individu mempengaruhi apa yang dipercaya dan apa yang akan dilakukan dalam kaitan dengan politik, khususnya preferensi dan perilaku politik. Prinsip ini diambil dari sebuah pandangan mendasar tentang persepsi, kognisi, dan aksi: bahwa manusia adalah mahluk sosial. Saat individu berinteraksi dan mengantisipasi interaksi, masing-masing individu mempengaruhi apa yang akan dipikirkan, dinilai, dan dilakukan individu lainnya.Ketikaindividumengambilkeputusan, mereka mendasarkannya pada berbagai tanda, pengetahuan, nilai, dan harapan dari pasangan, orang tua, anak, teman, teman kerja, dan lainlain yang ada di sekeliling - individu yang signifikan bagi kehidupan mereka. Individu mengikuti apa yang dilakukan beberapa teman sejawat mereka, mengabaikan yang lain, atau mungkin memilih untuk melakukan apa yang berbeda dengan kebanyakan individu lainnya.

Berlandaskan pada latar belakang diatas, studi ini menekankan pada pola jaringan para pemilih pemula di dalam sosial media dan pengaruh pola jaringan tersebut dalam partisipasi politik para pemilih pemula. Media sosial meningkatkan fleksibilitas dalam mendiskusikan politik dan masalah publik melalui koneksi "di mana saja, kapan saja". Komunikasi politik di dalam situs jaringan sosial berhubungan dengan partisipasi politik, dibarengi dengan adanya asosiasi antara partisipasi politik secara online dengan offline.

Kadushin (2012) menjelaskan bahwa jaringan (network) tidaklah sama dengan berjejaring (networking), Berjejaring adalah secara aktif menggunakan sebuah jaringan 
untuk membuat koneksi dalam mencapai tujuan tertentu. Boyd \& Ellison (2008) bahkan secara tegas membedakan jaringan sosial (social network) dengan berjejaring sosial (social networking) berdasarkan penekanan serta ruang lingkup. Jaringan sosial adalah sebuah layanan berbasis web yang mengalokasikan satu tempat bagi individu untuk membangun profil publik atau semi-publik dalam sebuah sistem tertutup, mengartikulasikan daftar pengguna lainnya yang berbagi layanan web yang sama untuk saling berbagi daftar koneksi didalam sistem tersebut. Sifat dan klasifikasi dari setiap koneksi berbeda-beda dari satu situs ke situs lainnya (Boyd \& Ellison, 2008; Leon-Abao, et.al., 2015). Sementara berjejaring sosial merupakan sebuah aktivitas (a practice) membuat kontak dan saling berbagi informasi dengan orang lain, grup ataupun institusi (Leon-Abao, et.al, 2015).

Berjejaring sosial biasanya terjadi pada individu yang memiliki kesamaan minat. Berjejaring sosial juga memberikan kemampuan bagi individu untuk membuat dunia lebih terbuka dan saling terhubung. Hal inilah yang menjadi alasan utama mengapa Situs Jejaring Sosial (Social Networking Sites - SNS) dewasa ini sangat popular, karena membuat individu bisa saling berbagi. Green, et.al. (2014) menyatakan bahwa saling berbagi adalah sebuah aktivitas manusiawi yang paling mendasar dan situssitus jejaring sosial dapat dipandang sebagai sebuah jalan mudah untuk "terkoneksi di tengah dunia yang terputus".

Jejaring sosial merupakan bagian dari sosial media. Walaupun keduanya memiliki kemiripan, tetapi secara konseptual keduanya adalah berbeda. Dalam konsep jaringan, media sosial merupakan alat yang memfasilitasi proses berjejaring. Hartshorn (2010) menjelaskan beberapa perbedaan jejaring sosial dengan media sosial. Pertama, merujuk pada definisi, media sosial adalah sebuah jalan ( $a$ way) untuk mentransmisi, atau membagi informasi dengan khalayak yang lebih luas, sementara jejaring sosial merupakan sebuah cara untuk terlibat (an act of engagement) dengan kelompok individu dengan minat yang sama, saling terhubung dalam situs jejaring sosial dan membangun hubungan melalui komunitas yang terbentuk. Kedua, merujuk pada gaya berkomunikasi, media sosial adalah saluran komunikasi yang analog, sebuah sistem yang menyebarluaskan informasi "pada" orang lain, sementara jejaring sosial merupakan komunikasi dua arah. Seperti televisi, radio, atau surat kabar, media sosial bukanlah sebuah lokasi untuk dikunjungi, sementara jejaring sosial, tergantung topik, masalah, atau atmosfer yang sedang berkembang, individu datang bersamaan untuk saling berkumpul dengan pengalaman dan latar belakang yang serupa. Percakapan merupakan inti dasar dari jejaring sosial dan melalui percakapan itulah hubungan sosial akan semakin terbentuk. Ketiga, dari perspektif respon waktu, media sosial memerlukan waktu yang lebih lama untuk diikuti, sementara jejaring sosial, karena merupakan komunikasi langsung antara individu terpilih, percakapan menjadi lebih kaya, lebih bertujuan, dan lebih personal. Jaringan akan tumbuh membesar saat 
individu bertemu dan diperkenalkan dengan individu lainnya.

Secara konvensional jaringan dihubungkan dengan sekelompok orang yang tinggal berdekatan serta saling berinteraksi satu sama lain secara regular. Dalam komunitas tradisional, individu harus hidup bersama dan melakukan banyak kompromi serta akomodasi agar dapat menikmati kenyamanan hidup bersama. Tetapi, dalam komunitas virtual kita dapat mengunjungi komunitas virtual tanpa memandang lokasi dimana kita berada, dapat keluar dari jaringan tersebut seketika hanya dengan satu kali klik. Kita bebas untuk berpartisipasi dalam jaringan kapan saja kita mau, untuk kemudian keluar kapan saja kita mau. Kita tidak perlu mengakomodasi orang lain ataupun topik-topik yang tidak menarik perhatian kita. Komunitas dan jaringan virtual ini menawarkan banyak keuntungan tanpa keharusan untuk bertanggung jawab dengan semua hal yang berlaku pada komunitas dan jaringan fisik -tanggung jawab untuk beradaptasi dan mengakomodasi yang lain, serta, diatas semuanya, tanggung jawab untuk tetap bertahan tinggal dan menjadi bagian didalam komunitas atau jaringan tersebut.

Politik berhubungan dengan perumusan dan pelaksanaan keputusan yang mengikat keseluruhan populasi yang mengikatkan diri mereka dalam sebuah kesatuan serta hubungan antara mereka yang melaksanakan keputusan tersebut dengan mereka yang terkena dampak dari pelaksanaan keputusan tersebut (Johnston, 2009). Miriam Budiardjo (1998) mendefinisikan politik sebagai "berbagai aktivitas dalam sebuah sistem politik (atau negara) yang melibatkan proses perumusan tujuan untuk sistem tersebut dan cara untuk mencapai tujuan-tujuan tersebut“". Menurut istilah Munroe (2002), aktivitas politik diatas berhubungan dengan "any regarding authority in general and government in particular". Bentuk paling mendasar dari perilaku politik adalah partisipasi politik. Munroe (2002) mendefinisikan partisipasi politik sebagai "the extent to which citizens use their rights, such as the right to protest, the right of free speech, the right to vote, to influence or to get involved in political activity."

Riset awal yang dilakukan oleh Campbell \& Kwak (2011) menyatakan bahwa komunikasi politik di dalam situs jaringan sosial berhubungan dengan partisipasi politik; memberikan efek moderat yang signifikan bagi mereka yang berpendirian tegas, tetapi tidak bagi mereka yang berpikiran sempit, serta dibarengi dengan adanya asosiasi antara partisipasi politik secara online dengan offline. Media sosial juga meningkatkan fleksibilitas dalam mendiskusikan politik dan masalah publik melalui koneksi "dimana saja, kapan saja”. Bucy, D'angelo \& Newhagen (dalam Mustaqim, et.al, 2016) menemukan bahwa penggunaan media, termasuk Internet, mendorong partisipasi politik dibanding keterasingan politik.

Irwansyah (2012) menjelaskan bahwa Internet memungkinkan terciptanya sebuah "ruang" yang mampu memfasilitasi diskusi dan saling berbagi berbagai isu yang berhubungan dengan masyarakat luas. Internet juga membantu partisipasi politik tradisional seperti menghubungi politisi, menandatangani petisi, atau memberikan donasi dapat dilakukan dengan lebih mudah dan 
cepat dari sisi waktu serta mengurangi biaya yang biasanya muncul dalam organisasi dan koordinasi massa dalam skala besar.

Price and Cappella (2002) menemukan diskusi politik meningkatkan keterlibatan warga; 60 grup warga negara dihubungkan setiap bulan dengan diskusi tentang isu politik dan kampanye presiden. Ditemukan argumen pro dan kontra yang lebih intens atas isu-isu yang sebelum diskusi sudah mereka bicarakan. Perubahan ini berkorelasi dengan peningkatan pengetahuan politik peserta. Diskusi online tersebut membuat sikap dan perilaku peserta terbentuk; mereka yang sebelumnya terlibat dalam diskusi secara online cenderung untuk menggunakan hak pilih dan melakukan kewajibannya sebagai warga negara dibandingkan dengan mereka yang tidak berpartisipasi dalam diskusi (dalam Irwansyah, 2012).

Hampir serupa, Gil de Zuniga dan Zheng (2014) mengemukakan sejumlah hasil penemuan mereka tentang peran media sosial terhadap partisipasi politik. Pertama, media sosial digunakan secara luas sebagai sumber berita. Orang mencari informasi via media sosial karena media sosial menyediakan informasi secara cepat dan dengan cara yang sangat fleksibel. Lebih lanjut, media sosial membuat berita menjadi lebih interaktif, karena itu mendorong partisipasi politik. Ketika membaca berita di media sosial, seseorang dapat membagi opininya dengan cara mentioning, meneruskan pada yang lain, atau mendonasikan dan memilih melalui media sosial. Kedua, semakin orang berpaling pada media sosial agar tetap up-todate dengan apa yang sedang terjadi di sekitar mereka, semakin tinggi juga kecenderungan mereka untuk berpartisipasi dalam aktivitas politik yang demokratis. Ada hubungan antara penggunaan media sosial untuk berita dengan ekspresi politik di media sosial. Ketiga, ada hubungan yang kuat antara ekspresi politik di media sosial dengan partisipasi politik, baik secara online maupun offline.

Himelboim (2012) mengemukakan bahwa minat dalam interaksi interpersonal tentang isu politik dan mengkonsumsi isi tentang isu politik memberikan peningkatan terhadap pemahaman dan dapat meramalkan perilaku terhadap aktivitas politik secara online. Semakin terbuka secara politik, individu akan menunjukkan semakin tinggi penggunaan media online secara multi-directional.

Data dari www.wearesocial.org mencatat bahwa pengguna Internet di Indonesia per Januari 2016 adalah sebanyak 88,1 juta dengan tingkat penetrasi mencapai 34\% dari keseluruhan populasi. Dari jumlah tersebut, 79 Juta diantaranya adalah pengguna aktif media sosial dengan lama penggunaan hampir 3 jam per hari. Akhir Februari 2012, jumlah pengguna Facebook di Indonesia telah melebihi 43 juta orang, ketiga terbesar setelah Amerika dan India. Indonesia juga berada pada posisi kelima di dunia untuk pengguna Twitter (Lim, 2012). Tetapi, angka-angka tersebut tidak menjamin peningkatan partisipasi politik, walaupun Luengo (2006) menemukan bahwa penggunaan Internet memberikan korelasi positif terhadap aktivitas politik. Penelitian yang dilakukan oleh Forrester Research (dalam Irwansyah, 2012) menemukan bahwa kaum muda menyerap media digital 
dalam kehidupan mereka dengan lebih cepat dibandingkan dengan generasi lainnya. Semua generasi sebenarnya mengadopsi teknologi Internet, tetapi konsumen yang lebih muda adalah Net Natives. Karena itu, ketika politik memasuki Internet, media baru maupun media sosial, generasi yang lebih muda akan terlibat dengan politik di dalam media interaktif dan mampu mengembangkan demokrasi digital. Hamid (2013) dari Change.org menyatakan bahwa minat dan partisipasi politik para netizen terbagi dalam dua kelompok besar, satu kelompok adalah mereka yang aktif secara politik di media sosial akan berpartisipasi juga secara aktif di Pemilu, tetapi sebaliknya, ada sekelompok netizen aktif di media sosial yang berpartisipasi aktif dalam bentuk aktivitas politik yang lain.

Hasil penelitian yang pernah dilakukan tentang "Peran Media Sosial terhadap Partisipasi Politik Pemilih Pemula dalam Pemilu 2014" (Perangin-angin, 2014) mengkonfirmasi apatisme para pemilih pemula dalam Pemilu 2014. Pemilih pemula diwakili oleh 1028 orang siswa sekolah menengah atas, baik SMU maupun SMK, sekolah negeri maupun swasta di 6 kota di Indonesia; Jakarta, Bandung, Surabaya. Jogja, Solo dan Serang. Hasil penelitian menunjukkan bahwa penggunaan media sosial di kalangan pemilih pemula berada pada kategori Sedang $(58,4 \%)$, tetapi partisipasi politik mereka berada pada kategori Rendah (88,1\%). Artinya, sebagian besar dari pemilih pemula sudah menggunakan media sosial sebagai salah satu alat berinteraksi, walaupun pola penggunaan tersebut masih dibatasi karena beberapa alasan seperti keterbatasan akses Internet ataupun waktu luang karena sibuk menyelesaikan tugas-tugas sekolah. Nilai partisipasi politik yang rendah menunjukkan bahwa hampir seluruh responden tidak menggunakan hak politik mereka pada Pemilu 2014, baik partisipasi offline maupun partisipasi online. Korelasi antara kedua variabel tersebut menunjukkan angka 0,423 atau ada hubungan tetapi tidak cukup kuat. Artinya, ada hubungan, walaupun kecil, antara penggunaan media sosial dengan partisipasi politik para pemilih pemula pada Pemilu 2014, atau dengan kata lain dapat disimpulkan bahwa tingkat penggunaan media sosial para kawula muda akan mempengaruhi tingkat partisipasi mereka di dalam politik. Tetapi, nilai korelasi tersebut juga menunjukkan bahwa hanya $42,3 \%$ dari partisipasi politik pemilih pemula yang dapat dijelaskan dengan pola penggunaan media sosial, selebihnya dipengaruhi oleh faktorfaktor lain.

Diperlukan studi yang lebih mendalam tentang sistem jaringan sosial yang dibangun oleh para pemilih pemula di dalam media sosial sehingga dengan temuan tersebut, pemanfaatan media sosial dapat lebih ditingkatkan pada pemilu mendatang untuk meningkatkan partisipasi politik para pemilih pemula. Merujuk pada latar belakang yang telah dipaparkan, tujuan penelitian ini adalah untuk mengidentifikasi jaringan sosial para pemilih pemula di dalam media sosial serta pengaruhnya pada partisipasi politik.

\section{Metode Penelitian}

Penelitian ini menggunakan pendekatan kualitatif untuk memfasilitasi studi yang lebih mendalam dan mendetil. Studi deskriptif dilakukan khususnya untuk pemetaan perilaku 
pemilih pemula dalam menggunakan media sosial, terutama aspek demografi dan psikografi serta pengaruhnya terhadap partisipasi politik. Unit analisis penelitian adalah individu.

Penelitian ini ditujukan pada para pemilih pemula yang baru pertama kali menggunakan hak pilih mereka pada Pemilu 2014. Sampel dipilih secara purposif di 3 kota besar di Indonesia, yaitu Bandung, Surabaya dan Jakarta. Kota Bandung dan Surabaya dipilih karena keduanya merupakan ibukota propinsi yang memiliki jumlah pemilih terbanyak pada Pemilu 2014. Selain itu, kedua kota tersebut bersama dengan kota Jakarta merupakan kota-kota yang memiliki sejumlah universitas dengan reputasi yang baik. Untuk kota Bandung, universitas yang terpilih adalah ITB, UNPAS, dan UNPAD. Untuk kota Surabaya, universitas yang terpilih adalah Universitas Widya Mandala, sedangkan untuk Jakarta, universitas yang terpilih adalah UNJ, SGU, dan UI.

Data penelitian dikumpulkan melalui kegiatan focus group discussion (FGD) dan semi-structured interview kepada 63 orang mahasiswa dari universitas yang disebutkan diatas. Sampel diambil dari mahasiswa tingkat awal di sejumlah universitas, karena mereka adalah pemilih yang baru saja mengikuti Pemilu di tahun 2014 yang lalu. FGD adalah sebuah teknik pengumpulan data penelitian melalui kegiatan diskusi kelompok yang pesertanya terbatas (dipilih) menurut kriteria tertentu dan pembahasannya memfokuskan pada topik (materi) tertentu yang sangat spesifik, yaitu tentang jejaring sosial dan pengaruhnya pada partisipasi politik pemilih pemula. Sedangkan untuk wawancara mendalam, kegiatan ini hanya dilakukan pada beberapa orang peserta saja untuk lebih mendalami hasil diskusi yang telah dilakukan sebelumnya.

Kegiatan Diskusi tatap muka dilakukan dengan rincian kegiatan sebagai berikut, pertama, di kampus Fakultas Ilmu Komunikasi, Unversitas Widya Mandala Surabaya, pada tanggal 21-25 Juni 2016, dengan jumlah total 20 peserta. Diskusi dan wawacara tatap muka dilakukan pada tanggal 23 dan 24 Juni 2016, yang diikuti oleh 20 orang peserta mahasiswa Fakultas Ilmu Komunikasi dari universitas tersebut. Kegiatan diskusi dilakukan dalam 2 tahap yaitu masing-masing 10 orang untuk setiap kelompok diskusi dikarenakan jumlah peserta cukup banyak. Tanggal 22 Juni 2016 diadakan rapat persiapan untuk membicarakan berbagai hal yang berkenaan dengan penyelenggaraan kegiatan diskusi tatap muka. Dalam analisis, partisipan diberi kode \#S120. Diskusi di Jakarta yang dilakukan dengan 7 orang mahasiswa Universitas Negeri Jakarta pada tanggal 19 Juli 2016 di lokasi sekitar kampus Fakultas Ilmu Pendidikan Psikologi UNJ. Pada analisis, partisipan diberi kode \#J18-24.

Kedua, pada tanggal 2-3 September 2016 dilakukan kegiatan diskusi di kota Bandung. Tanggal 2 September, diskusi dilakukan dengan 10 orang mahasiswa Program Studi Ilmu Informatika Universitas Pasundan Bandung. Dalam analisis, partisipan diberi kode \#B1-10. Kemudian pada tanggal 3 September dilakukan 2 kali kegiatan diskusi masing-masing dengan 4 orang mahasiswa Fakultas Ilmu Psikologi Universitas Padjajaran di area kampus Jatinangor. 
Dalam analisis, partisipan diberi kode \#B1115. Kemudian untuk sesi berikutnya diskusi dilakukan dengan 5 orang mahasiswa Fakultas Ilmu Komunikasi Universitas Padjadjaran. Pada analisis, partisipan diberi kode \#B15-19.

Ketiga, pada tanggal 12 September 2016 dilakukan kegiatan diskusi tatap muka dengan 5 orang mahasiswa di lokasi sekitar Taman Mini. Peserta berasal dari beberapa perguruan tinggi negeri dan swasta yang berdomisili di sekitar wilayah Taman Mini. Pada analisis, partisipan diberi kode \#J13-17.

Keempat, di kampus Universitas Swiss German dilakukan diskusi tatap muka dengan 12 orang mahasiswa program studi Ilmu Komunikasi pada tanggal 23 September 2016. Pada analisis, partisipan diberi kode \#J1-12

Jumlah total peserta diskusi tatap muka per kota adalah untuk kota Surabaya 20 orang, kota Bandung 19 orang, dan kota Jakarta 24 orang. Total ada 63 orang yang menjadi partisipan diskusi dalam riset ini. Peneliti bertindak sebagai moderator yang mengatur lalu lintas diskusi dan tidak berhak mempengaruhi pendapat dan sikap peserta diskusi. Semua hasil diskusi dicatat/direkam, dan hasilnya disajikan secara tertulis dalam bentuk verbatim, berupa transkrip. Hasil transkrip disusun dan digunakan untuk menjawab permasalahan yang diteliti.

Data yang sudah dikumpulkan diolah dan dianalisis secara deskriptif. Hasil yang didapat dari wawancara dianalisis dengan Tabel Triangulasi untuk kemudian dituangkan dalam gambaran umum dan analisa permasalahan dalam bentuk narasi, ungkapan, ataupun disajikan dalam bentuk deskripsi untuk mendukung analisis.

\section{Hasil Penelitian dan Pembahasan}

Profil partisipan dalam penelitian ini adalah mayoritas perempuan dibandingkan dengan laki-laki, dengan rentang usia antara 18-22 tahun. Semua partisipan adalah pemilih pemula yang baru memulai aktifitas politiknya dalam Pemilu 2014 yang lalu. Dari sisi agama, 35 orang beragama Islam, 20 orang Kristen, dan 8 orang Katolik dengan status sosial dan ekonomi hampir semua peserta berada pada kategori menengah ke atas, yang ditandai oleh sejumlah indikator seperti banyaknya uang jajan per bulan, kepemilikan mobil pribadi maupun frekuensi berlibur keluarga dalam setahun lebih dari 2 kali. Sebagian besar peserta tinggal bersama dengan orangtua, tetapi sejumlah partisipan lain mengaku tinggal sendirian atau kost karena berasal dari luar daerah.

Berkaitan dengan hubungan sosial, hampir semua peserta mengaku memiliki hubungan yang sangat baik dengan kedua orang tua maupun saudara kandung mereka, karena masih tinggal bersama dengan keluarga. Hanya beberapa orang saja yang harus tinggal terpisah dengan keluarga karena lokasi tempat tinggal yang cukup jauh atau berada di luar kota tempat mereka menempuh studi. Mereka mengaku masih bisa berdiskusi dan membicarakan berbagai hal dengan orang tua dan saudara kandung. Tetapi intensitas dan durasi berkomunikasi itu hanya sebentar, karena pagi hari sudah berangkat ke kampus dan baru kembali ke rumah menjelang malam hari. Para peserta mengaku bahwa intensitas komunikasi sangat sedikit di hari-hari sekolah, tetapi di akhir minggu bisa ditingkatkan. 
Perihal hubungan sosial dengan lingkungan sekitar, hampir semua mengaku hubungan sangat renggang karena jarang berinteraksi dengan tetangga. Hanya beberapa orang peserta yang mengaku sering berinteraksi dan berkumpul dengan tetangga, sementara sisanya mengaku hanya mengenal tetangga mereka tanpa pernah berkomunikasi. Semua peserta mengaku tidak pernah berdiskusi tentang politik dengan lingkungan sekitar, bahkan juga saat aktivitas politik seperti pemilihan umum sedang berlangsung tidak ada diskusi yang dilakukan dengan tetangga sekitar. Ketika ada partisipan yang mengakui adanya hubungan baik antar-tetangga di tempatnya bermukim, hubungan sosial saat ini juga menjadi agak renggang karena adanya perbedaan preferensi politik, apalagi pada saat Pemilu, seperti yang disebutkan dibawah ini:

"Karena saya, untuk di kampung saya mungkin sama seperti Reza tetapi penduduk rumah disitu kebanyakan pendatang. Dan saya juga Muslim. Otomatis ketika kita ibadah sholat pun itu pun kita ikut ngumpul. Tapi yang ngumpul-ngumpul itu bukan anak muda. Atau semua orang tua. Tetapi anak muda dengan orang tua-tua. Begitu. Karena yang di masjid sekarang itu kebanyakan yang sudah tua-tua yang tujuannya ya tobat dan sebagainya. Tapi untuk kanan kiri tetap tahu. Hanya tahu saja sih. Kenal. Tapi ketika apa yang sedang digosip-gosipkan atau sedang hangat karena ketika kita tahu berita yang dibuat, kita bisa tahu memutuskan kita harus seperti apa ... kalau diskusi politik iya ada. Sampai kita kumpul di pos itu buat ngomongin masalah politik kalau misalnya pemilu, biasanya dibicarakan. Iya, karena jujur aja di kampung itu pendatang. Mayoritas pendatang. Pemilihnya pun ada kubukubu seperti itu. Jadi sampai ada debat. Sampai ada gap. Ga ngomong atau mungkin saling menghindar. Ada juga. Alasannya, kuatnya. Seperti itu ... Kadang sampai di TPS pun itu kita tuh ada berbeda. di TPS, tapi ga ribut. Soalnya sudah tahulah pasti menang ini, pasti menang itu ..." (Partisipan \#S2)

Saat interaksi denganteman sekampus maupun luar kampus, hampir semua juga menyatakan memiliki hubungan yang sangat erat dengan teman-teman sekampus karena sebagian besar dari peserta diskusi adalah mereka yang aktif dalam organisasi kampus. Sebagian besar partisipan orang mengaku aktif di organisasi kampus, bahkan menjadi pengurus di organisasi tersebut. Bahkan banyak juga diantara mereka yang juga mengaku sangat aktif dalam kegiatan organisasi pemuda di lingkungan tempat ibadah mereka masingmasing, atau menjadi anggota, bahkan pengurus lembaga non pemerintah, atau organisasi pemuda kedaerahan.

Perihal kaitannya dengan intensitas terhubung dengan Internet, ada beberapa hal yang bisa dilakukan oleh netter, misalnya bermain games online, browsing informasi, atau menggunakan media sosial. Eikenberry (2012) menyebutkan paling tidak ada 6 jenis tipe media sosial, (1) collaborative project, seperti wikis dan aplikasi buku, (2) blogs, (3) content information, situs yang memfasilitasi sharing isi media antara pengguna, seperti Google docs atau YouTube, (4) virtual game world, (5) virtual social world, seperti Second Life, dan (6) social networking sites, seperti Facebook, LinkedIn, dan Twitter.

Pada penelitian ini, konsep terhubung dengan Internet adalah ketika jari menyentuh dan memainkan alat yang digunakan, bukan pada ukuran waktu ketika modem atau wi-fi terhubung dengan internet. Beberapa peserta mengaku tidak pernah mematikan wi-fi atau modem, tetapi tidak melakukan aktivitas apapun yang berhubungan dengan situssitus Internet, hal ini tidak termasuk dalam kategori terhubung dengan Internet.

Merujuk pada konsep keterhubungan dengan Internet serta media sosial, para 
pemilih pemula mengaku menghabiskan waktu antara 6-12 jam per hari untuk terhubung dengan dunia maya. Sebagian kecil partisipan mengaku mengakses Internet kurang dari 5 jam sehari. Sebagian lagi mengaku mengaktifkan Internet dan media sosial selama 5-10 jam sehari, sementara sebagian besar mengaktifkan Internet dan media sosial lebih dari 10 jam sehari. Bahkan, sebagian lainnya mengaku tidak pernah mematikan Internet dan media sosial mereka, seperti disebutkan berikut ini: "Saya gimana ya ... saya dibilang 24 jam bisa. Itu gimana ya. Saya ga sepenuhnya pakai. Kayak saya download sesuatu, saya tinggal semalaman gitu. Tapi kalau misalnya saya benar-benar pakai sekitar 15 jam. Sosial media kira-kira 10 jam." (Partisipan \#J13)

"Kalau Internet hampir tidak pernah dimatikan. Koneksi 6 jam, sosial media sepanjang hari. Selalu dicek grup. dari tidur sampai bangun." (Partisipan \#B3)

"Saya mungkin connect 19 jam ya. Sos-mednya paling 14 sampai 15 jam." (Partisipan \#J1)

"Sosial media kan di HP, jadi bisa dibilang 10 jam. Berarti 16 jam, Internetnya 6 jam, sosial medianya 10 jam." (Partisipan \#J3)

Peralatan utama yang digunakan para partisipan untuk mengakses Internet maupun media sosial adalah telepon genggam yang dimiliki secara pribadi maupun peralatan pendukung lainnya seperti komputer jinjing, modem dan wifi, yang juga sebagian besar dimiliki secara pribadi. Hampir semua peserta menyatakan bahwa telepon genggam selalu berada dalam genggaman tangan atau paling tidak selalu berada dekat mereka. Sedangkan untuk lokasi menggunakan internet, sebagian besar menyatakan bahwa mereka biasa berselancar di dunia maya saat sedang berada di rumah atau kampus. Ada beberapa orang dari peserta yang mengaku mencari kesempatan berselancar di mall atau ruang publik lain yang memberi akses berinternet secara gratis.

Perihal media sosial, semua peserta mengaku paling tidak memiliki 3 akun media sosial, terutama di media sosial seperti Path, Line, dan Instagram. Selain itu, akun media sosial lainnya yang mereka miliki adalah WA, Snapchat, Telegram dan AskFM. Beberapa media sosial yang dulu cukup terkenal seperti Facebook dan Twitter saat ini tidak menarik lagi bagi para pemilih pemula. Mereka mengaku masih memiliki akun-akun tersebut, tetapi tidak pernah atau jarang sekali membukanya.

Para peserta juga lebih tertarik dengan situs media sosial yang memungkinkan mereka untuk berkumpul dalam satu grup, seperti Line atau Whatsapp (WA), sehingga mereka dapat menggunakan media sosial itu juga sebagai alat berkomunikasi. Seperti yang disebutkan beberapa partisipan alasan mereka menggunakan Line atau WA adalah berikut ini :

"Kalau untuk internetnya kira-kira 11 jam-lah. Sosial medianya bisa 15-16 jam. Saya kadang sering buka Line." (Partisipan \#J4 )

"Line ini biasanya, Line itu tiap saat, Soalnya kontak sama orang lewat Line ... itu saya ga bisa sebutin dong berapa jamnya ... jadi khan buka, terus tutup lagi, buka yang lain ... chat, baca newsnya." (Partisipan \#S15)

"Karena update hal baru, jadi kayak sejam gitu udah beda lagi kegiatannya, topik baru ... Tapi kenapa harus 12 jam? Kenapa harus 8 jam? Karena kepo." (Partisipan \#S14)

"Kalau Line tahan sampai 2 jam - 3 jam soalnya banyak grupnya" (Partisipan \#S16)

Situs lain yang menjadi favorit bagi para pemilih pemula adalah Instagram dan Path. Sejumlah alasan menggunakan situs ini 
dikemukakan, seperti stalking atau mencari tahu aktivitas orang lain, memamerkan aktivitas personal, dan lain sebagainya, seperti yang disebutkan oleh beberapa partisipan berikut ini:

"Jadi pegang HP buat update. Kalau banyak media sosial itu nunjukin gaya hidup kita. Misalnya kita lagi bareng-bareng, check-in path. Eksis di dunia maya itu sudah suatu kayak kebutuhan soalnya nunjukin status sosial kita, ketika gak update ada perasaan apa ... mungkin susah." (Partisipan \#B19)

"Biasa 10-12 jam, sosial media 7 jam, biasa buka Line, Instagram ... di tempat bagus masa ga pamer ya?" (Partisipan \#B17)

"8-12 jam, media sosial 8 jam, biasa buka Line, Instagram, Path. Kecenderungan untuk selalu update itu selalu ... kayak ada yang kurang." (Partisipan \#B18)

"Keseringan buat chatting pake WA sama Line. Kalau stalking di Instagram." (Partisipan \#J15)

"Internet 12 jam, sosmed 10 jam, untuk Line, Snapchat, Instagram, askFM, Path ... stalking selebgram, teman .." (Partisipan \#B15)

"Kalau Instagram gitu, saya kadang lihat gitu saya lihat orangnya, saya scroll lagi ... Satu orang tuh bisa upload 2 foto. Begitu saya lihat follower saya ada 660. Coba 660 kali 2. Apa cukup tuh 8 jam? Ngerti ga sih? Kayak ada aja yang baru. Setiap saya scroll ada yang baru." (Partisipan \#J1)

"Karena rasa penasaran orang itu mungkin tinggi kali ... Kan misalnya, kalau kita lagi sendirian di rumah, kita gak tau harus ngapain. Bosan ... kan lihat Instagram karena kita penasaran gitu. Kita gak lihat apa-apa tapi rasa penasaran kita tinggi. Jadi buka Instagram, Path gitu ... efeknya itu cukup tahu ... kayak ngestalk terus tahu dia di sini ... kalau misalnya tempat yang teman kita datangi tempatnya bagus. Terus kayak oh coba deh ... dan ada beberapa kejadian mencoba gara-gara itu ... gara-gara ada gambar di Path ... sering banget ... jadi informasi yang disampaikan itu di follow up ... jadi bahan obrolan." (Partispan \#J5)

"Karena kalau lihat bisa sekalian ngebayangin." (Partisipan \#S16)

Para pemilih pemula juga mengaku menghabiskan banyak waktu dengan mengakses situs yang memfasilitasi saling berbagi isi media (content sharing) seperti YouTube karena banyak video menarik yang bisa dinikmati. Berbagai alasan menggunakan YouTube disebutkan sebagai berikut :

"Setiap hari nonton YouTube, kayak misalnya make up, kayak tutorial ... ini bisa sampai 12 jam ... Terus kaya short movie." (Partisipan \#S15)

"Vlog-vlog gitu. Video blogger, yang lucu-lucu, tutorial dance." (Partisipan \#S12)

"Karena di YouTube ada kayak misalnya yang main game. Tutorial. Ada yang bikin video kreatif. Ada video musik yang bisa dilihat. Kadang-kadang udah nonton satu video bisa nagih ke video yang lain lagi ...nyambung, nyambung, nyambung terus." (Partispan \#B2)

Penggunaan media sosial menjadi sangat penting sebagai alat untuk terus memelihara komunikasi, baik dengan anggota keluarga maupun dengan teman-teman. Peserta hanya membuka jejaring dengan orang-orang yang sudah pernah mereka kenal sebelumnya, misalnya anggota keluarga, teman semasa sekolah, atau teman dalam kegiatan diluar sekolah. Jejaring dengan orang baru atau yang tidak pernah dikenal sangat dihindari, sehingga jejaring didalam media sosial bukanlah jejaring baru, tetapi jejaring lama yang dipindahkan dari dunia realitas kedalam dunia maya. Hal ini disampaikan oleh beberapa partisipan sebagai berikut:

"Tapi nggak nge-add teman baru, karena seram." (Partisipan \#J3)

"Sosmed dibuat tidak hanya untuk new network tapi malah ke old network. Saya update sama temen sma kelas 10. Dalam tiap kelas ada gang. Ada 1 teman ada komen, 3 bersepuluh dari nama geng. Jadi dari satu upload bisa muncul lagi yang 10. akhirnya yang baru itu kembali berteman ... jadi grup yang ga pernah muncul jadi ribut lagi." (Partisipan \#B14)

Begitu juga untuk pola hubungan sosial didalam kampus atau organisasi. Semua peserta mengaku menggunakan media sosial, 
terutama grup-grup pertemanan sebagai alat komunikasi utama. Seharian bersama dalam aktivitas kampus dan organisasi tetap dianggap belum cukup, sehingga komunikasi intensif tetap dilakukan melalui media sosial. Koordinasi dan saling berbagi informasi menjadi alasan utama bagi para pemilih pemula ini untuk terus berkomunikasi lewat media sosial.

"Kalau misalnya di BPM itu, kalau misalnya, chatting itu biasanya sih, kalau misalnya, cuman bikin kordinasi rapatnya kapan. Terus kebetulan dicatatnya disitu. Terus, kalau mau dekatin antar angkatan, ini kan masih baru, masih banyak anggota baru. Aku harus mulai, apa sih, otomatis, harus mulai, maksudnya harus lebih instan sekarang, harus kenal satu sama lain dulu, kan. Tapi kalau misalnya tiga bulan sudah jalan periode, akan banyak ketemunya karena biasanya kan harus koordinasi secara langsung. Bukan lewat chat. Jadi ... jadi face to face-nya tetap, gak bisa di ilangin." (Partisipan \#S1)

"Kalau saya mungkin kalau secara, kalau misal bilang soal frekuensi, pasti akan lebih banyak frekuensinya di chat. Karena, kan, kalau meet-up itu kita pasti butuh waktu untuk bertemu. Gunanya chat itu untuk mengatur jadwal pertemuan itu. Jadi ... jadi, tetap dikoordinasikan. Kalau misalkan interaksi pun juga lewat chat. Karena, kan, sering kali, pengalaman kalau sendiri selama ini sebenarnya kalau kita face to face masih kalau pertama kali mungkin lebih canggung. Tapi, yang kita coba komunikasikan, saya mungkin nanti pertemuan selanjutnya bisa." (Partisipan \#S10)

Sistem sosial merupakan contoh paling konkrit dari sebuah jaringan. Dalam jaringan sosial, individu saling membangun hubungan -siapa berkomunikasi dengan siapa, siapa berkomunikasi secara regular dengan siapa. Chafee (1986) yang dikutip oleh Walther (2011) menyatakan peran konvergensi dan saling melengkapi dari saluran tradisional dan interpersonal dalam melakukan diseminasi pesan komunikasi. Teknologi komunikasi membuka akses pada informasi bukan hanya pada konvergensi media (televisi, surat kabar, film maupun Internet), tetapi juga pada konvergensi media yang lebih fundamental dari saluran massa, interpersonal maupun teman sejawat (peer).

Kekuatan dari jaringan sosial yang baru adalah karena adanya perbedaan dengan karakteristik jaringan sosial secara tradisional. Pada jaringan tradisional, atribut setiap personal menjadi sangat penting, apakah individu tersebut dianggap sebagai orang yang ramah atau kurang ramah, bodoh atau pintar, atau atribut lain yang melekat pada kepribadian sang individu akan sangat mempengaruhi bagaimana individu tersebut menjalin relasi dengan orang lain. Kemudian, dalam jaringan sosial baru, atribut-atribut personal itu menjadi sangat tidak penting dibandingkan dengan hubungan dan jalinan yang dirajutnya dengan orang lain didalam jaringan tersebut. Para peserta diskusi mengakui bahwa kekuatan dari jaringan sosial didalam media sosial adalah hilangnya identitas personal yang dilekatkan pada kepribadian mereka secara tatap muka. Pada saat berinteraksi di media sosial, mereka dapat menampilkan karakter lain dari yang bisa mereka tampilkan, misalnya biasanya pendiam, tetapi bisa aktif memberikan komentar ketika berinteraksi di media sosial.

Secara konvensional jaringan dihubungkan dengan sekelompok orang yang tinggal berdekatan serta saling berinteraksi satu sama lain secara regular. Pada komunitas tradisional, individu harus hidup bersama dan melakukan banyak kompromi serta akomodasi agar dapat menikmati kenyamanan hidup bersama. Tetapi, dalam komunitas virtual kita dapat mengunjungi komunitas virtual 
tanpa memandang lokasi dimana kita berada, dapat keluar dari jaringan tersebut seketika hanya dengan satu kali klik. Kita bebas untuk berpartisipasi dalam jaringan kapan saja kita mau, untuk kemudian keluar kapan saja kita mau. Kita tidak perlu mengakomodasi orang lain ataupun topik-topik yang tidak menarik perhatian kita. Komunitas dan jaringan virtual ini menawarkan banyak keuntungan tanpa keharusan untuk bertanggung jawab dengan semua hal yang berlaku pada komunitas dan jaringan fisikal -tanggung jawab untuk beradaptasi dan mengakomodasi yang lain, serta, diatas semuanya, tanggung jawab untuk tetap bertahan tinggal dan menjadi bagian didalam komunitas atau jaringan tersebut.

Mooney (2009) mencatat bahwa kekuatan lain dari interaksi lewat media sosial adalah bahwa aktivitas utama didalam media sosial adalah BERBICARA, bukan menulis. Berbicara adalah basis bagi sistem berinteraksi dan berkomunikasi. Para peserta menyatakan bahwa mereka merasa nyaman untuk mengeluarkan opini mereka tanpa takut teridentifikasi dengan mudah. Secara online, orang bebas mengekspresikan seluruh aspek diri mereka yang tidak mungkin dilakukan dalam kontak tatap muka. Saat terjadi ketidaksetujuan atas suatu idea yang dilontarkan, misalnya, mereka bisa langsung meninggalkan TEMPAT tanpa harus minta ijin dulu (yang tentunya akan dianggap tidak sopan dalam keadaan tatap muka) atau memberi komentar lain tanpa harus mempertimbangkan reaksi penerima.

Wigmore (2013) lebih lanjut menjelaskan bahwa media sosial merupakan "sekumpulan saluran komunikasi secara online yang dide- dikasikan untuk melakukan input, interaksi, diskusi isi, serta kolaborasi yang berbasis komunitas," karena itu, Mayfield (2008) mengemukakan sejumlah karakteristik dari media sosial yaitu partisipasi, keterbukaan, percakapan, komunikasi, dan keterikatan. Kemudian, dalam kaitan dengan peserta diskusi, kegiatan komunikasi yang paling intens dilakukan adalah memperhatikan berbagai foto-foto maupun status yang ditulis oleh teman-teman mereka di dalam media sosial, untuk kemudian foto dan status tersebut akan dikomentari ataupun didiskusikan.

Keputusan politik memang tidak diambil di dalam sebuah ruang hampa. Lingkungan sekitar individu akan mempengaruhi apa yang dipercaya dan apa yang akan dilakukan dalam kaitan dengan politik, khususnya preferensi dan perilaku politik. Ketika individu mengambil keputusan, mereka mendasarkannya pada berbagai tanda, pengetahuan, nilai, dan harapan dari individu yang signifikan bagi kehidupan mereka, seperti orang tua, teman, dan lain-lain yang ada di sekeliling Individu mengikuti apa yang dilakukan beberapa teman sejawat mereka, mengabaikan yang lain, atau mungkin memilih untuk melakukan apa yang berbeda dengan kebanyakan individu lainnya.

Salah satu kegiatan yang membantu para pemilih pemula dalam mengambil keputusan politik adalah adanya diskusi tentang politik dengan keluarga dan keluarga besar. Semua partisipan mengaku diskusi antar anggota keluarga berjalan dengan baik, ada waktu-waktu mereka bisa membicarakan banyak hal dengan orang tua, tetapi sayangnya diskusi politik hampir tidak pernah dilakukan. Namun, ada sebagian 
kecil partisipan mengaku berdiskusi politik dengan orang tua, bukan hanya tentang isuisu politik yang sedang hangat diberitakan oleh media lain, tetapi juga mereka bisa belajar praktek politik lewat bimbingan orang tua.

"Ngomong-in tentang perdagangan. Terus ya kayak partai-partai ... oh sampai ke partai ... sampai perilaku tokoh-tokoh partai, itu sampai dibicarakan. Karena keluarga juga kan ada yang terlibat. Kayak jadi bahan perbincangan." (Partisipan \#S15)

"Pernah ada omongan diskusi soal politik ... karena keluarga saya keluarga yang sangat tidak suka politik Indonesia, jadi sangat ... semuanya dikritik gitu ... kritik-kritik terhadap realitas politik. Kayak misalnya kalau ada highlight apa misalnya kayak, misalnya Ahok yang banjirbanjir itu dibahas ... jadi kalau ada isu-isu ..." (Partisipan \#B15)

"Karena, kalau saya pribadi saya tidak terlalu tertarik dengan politik. Kalau lihat kok malah jadi gak interest. Tetap ada diskusi sedikit-sedikit dari keluarga. Tapi masalahnya seringkali saya kalau pulang ke rumah itu sudah malam, jadi keluarga sudah istirahat. Sudah selesai nonton TV-nya. Tapi tetap didiskusikan. khususnya waktu hari pemilihan bahkan tetap pilih ini pilih ini. Tetap didiskusikan, tetap didorong. Tetap memilih sendiri. Tetapi tetap sebelum memilih didorong tapi tetap saya memilihnya pilihan saya sendiri, karena saya punya pertimbanganpertimbangan yang lain. Beda dengan pilihan orang tua." (Partisipan \#S10)

Diskusi politik dengan keluarga terjadi jika ada informasi, berita, atau isu politik yang hangat atau untuk kepentingan pemilihan yang terjadi lima tahun sekali. Informasi dan berita tersebut didapat dari berbagai sumber informasi untuk kemudian didiskusikan, seperti yang disebutkan oleh beberapa partisipan berikut ini :

"Kalau urusan politik sih kalau ada stimulusnya baru ngomongin tentang politik. Jadi kaya pas nonton TV misalnya ada Metro, TVOne. Soalnya mama sukanya nonton memang Metro sama TVOne, gitu. Jadi dia kadang suka komen suka cerita tentang apa yang dia tonton. Cuma aku kan memang gak begitu ngerti politik jadi ya ... oh iya ... iya. Ya gitu-gitu aja sih cuma respon ya... ya gitu gitu aja." (Partisipan \#S8)

"Kalau masalah politik di keluarga saya, kita sangat apa ... mengikuti acara yang lagi hits. Contohnya kalau ada pemilihan, TVOne pasti langsung ada debat. Itu tuh pasti langsung dicatat jadwalnya kapan. Tapi saya gak milih karena di keluarga saya tuh bukan tipe yang milih. Jadi kita gak milih. karena pertama kita keluarga pindahan dari Jember. Nah kita mau proses ke Surabaya ini jadi KTP-nya KK-nya semua, SIM Surabaya, eh sorry, Jember. Jadi saya kan harus pulang. Kalau pulang itu saya gak sempat." (Partisipan \#S9)

"Isu politik sih paling pas pemilu. Karena baru pertama jadi nanya ke orang tua ... Pas waktu 2014 ... iyakan jadi pemilih Itu nanyananya cara ke orangtua juga ... kalau milih itu di serahkan ke kita. Tapi calon-calonnya udah dikasih tau." (Partisipan \#B1)

Bahkan beberapa partisipan mengaku bahwa pilihan politik pun kemudian diatur oleh keluarga atau oleh partisipan, tergantung suasana diskusi yang terjadi, seperti yang disebutkan berikut ini :

"Karena dua tahun yang lalu tiga tahun yang lalu ketika umur tujuh belas yang diperkenalkan ke dunia politik oleh ibu saya sendiri. Dan langsung jadi simpatisan legislatif dia, walkot, pilgub sampai kemarin yang terakhir pilpres. Saya jadi simpatisan.” (Partisipan \#S2)

"Ada membicarakan keputusan ... Karena papa mama milih sama jadi cenderung milihnya jadi sama ..." (Partisipan \#B8)

"Kalau mempengaruhi sih malah saya yang mempengaruhi bukan orang tua saya. mungkin pengalaman kan tahun lalu, saya terlibat dalam politik, kan. Contohnya tahun lalu saya terlibat dalam kampanye politik kan. Yang menjadi wakil DPR di Surabaya itu kan Om saya. Jadi saya tahu caranya orang kampanye. Jadi saya turut serta dalam mempromosikan Om saya itu tadi. Jadi yang mempengaruhi justru saya bukan orang tua saya." (Partisipan \#S1)

Diskusi juga bisa terjadi dengan temanteman, terutama teman kampus dimana partisipan bergabung bersama dalam organisasi kemahasiswaan. Tetapi, diskusi tentang politik sendiri tidak terjadi didalam media sosial. Semua partisipan menyatakan bahwa didalam 
jaringan mereka didalam media sosial, diskusi tentang isu-isu yang berbau politik tidak terjadi karena beberapa alasan seperti yang disebutkan berikut ini:

"Ya kalau saya bicara di sosial media kan nggak semua orang nanggapi gitu ... di Line yang begitu aktif politik juga sangat jarang. Teman yang diajak bicara itu yang gak suka ..." (Partisipan \#S11)

"Pas pemilu baru ramai ... tetap gak bisa bu. Tetap ga ada jawaban ... bingung juga sama sifat kita nih. Harusnya ada perubahan tadi ya?" (Partisipan \#J1)

Perihal sumber berita dan informasi tentang politik, sebagian besar peserta mengaku mendapatkan informasi tentang politik terutama dari situs-situs berita online seperti detik.com atau kompas.com. Sebagian lagi mengaku menggantungkan informasi yang mereka dapat dari berita atau informasi yang dibagikan oleh teman-teman atau oleh grup media sosial. Jadi, kelompok ini tidak mencari berita atau informasi tentang politik, tetapi hanya secara pasif menunggu berita dan informasi yang masuk ke dalam akun media sosial mereka.

"Sharing berita dari teman. Kalau gak dapat sharing malah ga baca." (Partisipan \#J17)

"Sering lihat-lihat video di YouTube terus diinformasikan ke papa kalau Ahok beginibegini ..." (Partisipan \#S11)

"Karena semua informasi penting pasti di Line." (Partisipan S17)

Kemudian, untuk media konvensional, hanya sebagian kecil partisipan yang mengaku masih mendapatkan informasi dari televise. Media elektronik lainnya seperti radio atau media cetak malah tidak lagi menjadi sumber berita.

Setelah membaca sharing berita dari media sosial, hanya bebeapa orang partisipan yang mengaku kemudian berusaha mencari sumber resmi atau asli dari berita dan informasi tersebut secara online. Ada juga yang mengaku berusaha mencari penjelasan yang lebih mendalam dari media informasi lainnya, seperti media elektronik dan media cetak. Mereka hanya mencari berita atau informasi tentang politik yang menarik perhatian saja, misalnya isu-isu yang sedang hangat atau ketika ada kontroversi atas satu isu tertentu. Berita atau informasi tersebut kemudian didiskusikan dengan anggota keluarga mereka atau teman-teman mereka. Hasil diskusi dengan keluarga dan teman itu kemudian dipergunakan sebagai bahan rujukan dalam mengambil keputusankeputusan yang berhubungan dengan politik, misalnya untuk memilih pasangan presiden dan wakil presiden pada pemilihan umum.

Kegiatan partisipasi politik secara online yang biasa dilakukan adalah memberikan tanda like untuk informasi dan berita politik yang dibagi dari teman-teman yang lain atau komentar teman atas satu berita dan informasi yang dibagikan, kemudian meneruskan (forwarding) berita atau informasi tersebut kepada teman lainnya atau memberi komentar pribadi.

Hasil penelitian menunjukkan bahwa aktivitas partisipasi politik secara online masih kurang banyak dilakukan oleh para peserta kelompok tatap muka. Hanya beberapa orang saja yang mengaku pernah memberikan tanda suka (like) untuk berita atau informasi politik yang masuk dalam akun media sosial mereka. Seperti disebutkan oleh Partisipan \#S12 “Onlinenya sih ngelike ... ngelike berita-berita politik. Pasang foto profile juga. Pasang profile picture ... tapi itu waktu pemilu." 
Komunikasi politik di dalam situs jaringan sosial berhubungan dengan partisipasi politik, dibarengi dengan adanya asosiasi antara partisipasi politik secara online dengan offline. Media sosial juga meningkatkan fleksibilitas dalam mendiskusikan politik dan masalah publik melalui koneksi "di mana saja, kapan saja”.

Sebagian besar peserta ternyata belum berpartisipasi secara maksimal untuk partisipasi politik secara offline. Sebanyak 30 orang diantara peserta mengaku hanya melakukan kegiatan bertukar informasi tentang politik dengan teman atau keluarga. Ada 6 orang peserta yang mengaku pernah menjadi anggota partai politik, anggota tim sukses atau anggota tim relawan untuk calon anggota legislatif ataupun calon pasangan presiden. Sebanyak 6 orang juga yang mengaku pernah menghadiri rapat dalam hubungan dengan kegiatan politik maupun kegiatan kampanye politik. Dari 63 orang partisipan, hanya 22 orang diantara mereka yang ikut memilih dalam pemilihan anggota legislatif di Pemilu 2014, dan 35 orang yang mengaku ikut memilih presiden dan wakil presiden. Hanya 11 orang juga yang pernah melakukan aktivitas politik lainnya, seperti memasang stiker partai politik atau calon maupun kegiatan lain seperti memberi sumbangan.

\section{Simpulan}

Hasil penelitian yang dilakukan dapat ditarik kesimpulan sebagai berikut, (1) Media sosial telah digunakan secara luas dan massif oleh anak-anak generasi sekarang karena didalammedia sosial mereka dapat berinteraksi dan berkomunikasi secara nyaman tanpa harus memperlihatkan atribut-atribut kepribadian mereka secara terbuka. Mereka juga tidak mengalami masalah dalam mengakses internet, sehingga dapat terhubung dalam jaringan dengan intensitas yang sangat tinggi; (2) Saat berjejaring di dalam media sosial, mereka berinteraksi hanya dengan orangorang yang sebenarnya mereka telah kenal di dunia realitas, komunikasi dan interaksi dilakukan lebih intensif karena keterbatasan waktu dan tempat untuk berinteraksi akibat padatnya aktivitas harian yang harus dilakukan setiap harinya. Tetapi kesempatan untuk berinteraksi secara tatap muka di akhir minggu juga ternyata tidak dilakukan karena mereka sudah merasa nyaman untuk berinteraksi lewat media sosial yang tidak memerlukan persiapan fisik; (3) Media sosial juga saat ini menjadi sumber rujukan berita dan informasi politik bagi mereka. Jika diperlukan, atau merasa memerlukan informasi tambahan, mereka akan mencari informasi lewat media lain. Informasi yang didapat kemudian akan didiskusikan dengan keluarga atau temanteman sebelum mereka mengambil suatu keputusan politik; (4) Partisipasi politik mereka sangat rendah karena para peserta tidak memahami secara mendalam bahwa definisi politik sebenarnya menyangkut banyak hal dalam bidang kehidupan. Para peserta hanya mengkaitkan politik dengan partai politik dan aktor politik, karena itu mereka belum mengambil peran aktif dalam politik, baik secara online maupun offline.

\section{Daftar Pustaka}

Boyd, D.M. and Nicole B. Ellison.(2008). "Social Network Sites: Definition, History, and Scholarship." Journal of ComputerMediated Communication 13 (2208)@ International Communication Association. 
Budiardjo, Miriam. (1998). Dasar-Dasar Ilmu Politik. Jakarta : PT. Gramedia Pustaka Utama.

Campbell, Scott W. \& Nojin Kwak. (2011). "Political Involvement in 'Mobilized' Society: The Interactive Relationships among Mobile Communication, Network Characteristics, and Political Participation," in Journal of Communication 61 (2011) 1005-1024 (a)2011 International Communication Association.

Eikenberry, Angela M. (2012). Social Networking, Learning, and Civic Engagement: New Relationships between Professors and Students, Public Administrators and Citizens. http:// digitalcommons.unomaha.edu/ pubadfacpub/32.

Gil de Zuniga, Homero and Pei Zheng.(2014). Media social: a Driver for Improved Citizenship. http://www/polity.org.za/ article/social-media-a-driver-forimproved-citizenshipas as accessed $4^{\text {th }}$ April 2014

Green, Janet, Aileen Wyllie, Debra Jackson. (2014). "Social Networking for Nurse Education: Possibilities, Perils, and Pitfalls." In eContent Management Pty Ltd. Contemporary Nurse Vol. 47, Issue 1-2, April/June 2014.

Hamid, Usman. (2013). “Minat Politik Terbelah: Partisipasi Politik Anak Muda Berpotensi Lewat Media Social," http://m.facebook. com/notes/changeorg/minat-politikterbelah-partisipasi-partisipasi-politiknak-muda-berpotensi-lewat-media-sosial, August $5^{\text {th }}, 2013$, as accessed by August $23^{\text {rd }}, 2013$.

Hartshorn, Sarah. (2010). 5 Differences Between Social Media and Social Networking. http:// socialmediatoday.com/SMC/194754, as accessed by Sept $17^{\text {th }}, 2013$.
Himelboim, Itai. et.al. (2012). Social media and Online Political Communication: The Role of Interpersonal Informational Trust and Openness. Journal of Broadcasting and Electronic Media. 56:1, 92-115. http://dx.doi.org/10.1080/ 08838151.2011.64.8682.

Irwansyah. (2012). "Media social and Political Participation: Youth Activists' Perspective" in Communicate: Journal of Communication Studies. Vol. 5 No. 2 July - December 2012.

Johnston, Larry. (2009). Politics: an Introduction to the Modern Democratic State. Canada: University of Toronto Press.

Kadushin, Charles. (2012). Understanding Social Networks: Theories, Concepts, and Findings. USA: Oxford University Press, Inc.

Leon-Abao, E., et al. (2015). Engagement to Social Networking Challenges and Opportunities to Educators. European Scientific Journal, June 2015 edition vol.11, No. 16, p. 173-191.

Lim, Merlyna. (2012). "Media social and Political Mobilization" in The Indonesia Journal of Leadership.Policy and World Affairs Strategic Review. April-June 2012/Volume 2/Number 2, p. 52-60.

Luengo, Oscar Garefa. (2006). "E-activism: New Media \& Political Participation in Europe." Journal CONfines 2/4 AgostoDiciembre 2006, ISSN: 1870 - 3569. http://web2.mty.itesm.mx/temporal/ confines/articulos4/OLuengo.pdf, as accessed on October 31st, 2013.

Mayfield, Antony. (2008). What is Media social? E-book from ICrossing.co.uk as accessed on October $4^{\text {th }}, 2013$.

Mooney, Carla. (2009). Online Social Networking: Hot Topics. USA: Cengage Learning. 
Munroe, Trevor. (2002). An Introduction to Politics: Lectures for First Year Students. Jamaica: Stephenson's Litho Press.

Mustaqim, Asrul, et.al. (2006). "Hubungan Penggunaan Media dan Partisipasi Politik" in Jurnal IISIP, Juli 2006, Jakarta, p. 89-106.

Sodikin, Amir and Wisnu Nugroho (2013).“Demokrasi Era Digital: Mengejar Generasi Pedas, Lekas, dan Bergegas", in Kompas Daily, edition Friday, October $25^{\text {th }}, 2013$, p. 54.

Walther, Joseph B., et al. (2011), "Interaction of Interpersonal, Peer, and Media Influence
Source Online; A research Agenda for Technological Convergence," in A networked Self; Identity, Community, and Culture on Social Network Sites, edited by Zizi Papacharissi, New York: Routledge.

Wigmore, Ivy. (2012). "What is Media social?", http://whatis.techtarget.com/ definition/social-media, as accessed on September 12 2013.

Wood, Julia T., (2008). Communication Mosaics; an Introduction to the Field of Communication, USA: Thomson Wadsworth.

Zuckermann, Alan. (2005). The Social Logic of Politics: Personal Networks as Context for Political Behavior, the editor. USA: Temple University Press. 